\title{
Reflections on the social work profession on the 50th anniversary of ANZASW: Those who fail to learn from history are doomed to repeat it
}

\section{Caz Thomson}

Caz was raised in Wainuiomata, Wellington. She graduated with a Massey University BSW in 1991 and worked for the next three years with the Deaf Association in Auckland. She then travelled overseas for the following six years, working mainly for local councils in the UK as a care manager. She returned to NZ in 2000 and has worked in the field of psychogeriatrics ever since, for Hutt Valley, Greenwich and currently, Capital and Coast DHB.

\section{Abstract}

The 50th anniversary has provided an opportunity to reflect on the social work profession - where we have come from and where we are going. These reflections led me to two thoughts - are social workers leaders or followers in social change? And considering the change in our practice over the past 50 years, what might future social workers think of our current practice?

\section{Introduction}

Social workers in Aotearoa New Zealand 'advocate social justice and principles of inclusion and choice for all members of society' (ANZASW Code of Ethics). Over the past 50 years there has been a greater emphasis on human rights, social justice and tolerance of diverse lifestyles. Fifty years ago, women were paid less than men doing the same job, simply because they were women. It was illegal to be a homosexual. Maori and deaf children were still punished for using their own languages. There is still much to be done. The gap between men's and women's pay is currently increasing. Many people are caught in a poverty trap, denying them the same opportunities as the better off. And in many countries around the globe, freedom of speech is denied, along with the right to self-determination.

One question I have been asking myself recently is whether social work is at the vanguard of the improvement in human rights, or whether we are following the trend. This assumes, of course, that social workers are a homogenised group, and I think that is a fallacy. We may all aspire to the same principles, but some of us are actively working to achieve them on a macro level whilst others are working at a micro level only. This may be where they are most effective, or it could also be a reflection of wider social issues.

Fifty years ago the Western world was on the brink of massive social change and I have no doubt that many social workers were at the forefront of this change. But there were social workers employed by agencies who had policies that we would consider to be unjust and 
unfair. Presumably the social workers employed at that time did not think that. Children were removed from their parents' care, often for reasons we would consider minor or even irrelevant today - such as the child's mother being unmarried. But at the time I am sure the social workers involved in this activity must have believed they were doing the best thing for these children. They were no doubt trying to ensure these children had the best possible life and must have believed this was best achieved by placement with middle class families.

What has changed? Fifty years ago there was a greater paternalistic flavour to life in New Zealand and other developed countries. Today, we have a greater emphasis on autonomy and self determination. This is a core social work value. Did we help to create this?

Churchill, paraphrasing George Santayana, warned us that those who fail to learn from history are doomed to repeat it. This quote is apt here for two reasons. One is to help us reflect on the work we do now, and the other is to help us challenge unjust policies that may be proposed in the future.

\section{The work we do now}

Many social workers, including myself, are employed in agencies that use coercion in certain circumstances. In the area of mental health, this is both the Mental Health Act (MH Act) and the Protection of Personal and Property Rights Act (3PR Act). Both acts have criteria that must be met before they can be used, and there are checks and second opinions built into the legislation. But the fact remains that as a social worker in mental health, I can (and have) used these pieces of legislation to uplift someone from their home to take them to hospital or residential care against their wishes. I believe that I am acting in the best interests of vulnerable adults and in an ethically defensible way. But will the social workers in 50 years time see my work as abhorrent? Will they ask why a social worker would do such a thing.

There are other social workers who have coercion as a tool. Child, Youth and Family springs to mind and I would expect that social workers in Probation also have access to legislated forms of coercion.

\section{Future possible policies}

There are many children in New Zealand now living below the poverty line. Many of these children are going to school without breakfast or adequate clothing. It is not too hard to imagine a politician proposing that children who cannot have their needs met due to the poverty of their parents should be removed from their care. Of course, such a proposal would be met with an outcry from the public and, no doubt, from social workers. Removing children from their parents' care is a drastic response to a politically generated crisis - the causes of which include benefit cuts and a minimum wage that is below the living wage standard. Without political will to change the causes of poverty, children will continue to live without the basics of life. Imagine then, if it became law to remove these children and place them in care. If you were a social worker employed by CYFs, what would you do?

One of my colleagues who works in Probation has told me of a proposed law change that, if passed, would detain indefinitely criminals who have served their sentence, but are deemed an unacceptable risk to the public. The debate is over whether is it ethical to release 
someone into the community (eg a sex offender) who has a very high risk of reoffending, versus detaining someone who has served their sentence for past crimes, on the basis that they are likely to commit a crime in the future. If this law if passed, would you support it?

\section{Summary}

The 50th anniversary of ANZASW invites us to reflect on our work as social workers - where we have come from and where we are going. My only reflections have led me to consider what I am doing at a macro level, to challenge unfair and unjust practice and to speak out for the most vulnerable and least privileged members of our society. I have also been considering the work I do using legislated coercion and the need to be continually asking myself (and my colleagues) if there is another way to reduce the risk, without imposing an intervention on a person.

I also throw this challenge out to all of us as we celebrate our anniversary. 